\title{
THE ROLES OF PARENTS AND PEER FRIENDS ON ADOLESCENT PREMARITAL SEX BEHAVIOR IN HIGH SCHOOL STUDENTS OF BUOL DISTRICT
}

\author{
Nurhaya S Patui ${ }^{1}$, Djaswadi Dasuki ${ }^{2}$, Budi Wahyuni ${ }^{3}$
}

\begin{abstract}
Background: Most adolescents or teens consider premarital sex behavior is a common and normal activity to do. Parents less able to communicate with their children will provoke conflicts in parents-children relationship and this may lead to impacts on premarital sex behavior in adolescents. Peer friends are also a source of information about sex that is quite significant in the shaping of adolescent knowledge, attitude and sexual behavior. However, information from peers may lead to negative impacts in adolescents such as premarital sex. This activity can lead to unwanted pregnancy, STIs, abortion and school dropouts.

Objective: To determine the relationship between the roles of parents and peers in adolescent premarital sexual behavior in SMAN 1, SMA 2, SMK 1 and MAN in Buol.

Methods: This study was observational with a cross-sectional design using quantitative and qualitative approaches. The study was held in SMAN 1, SMAN 2, SMK 1 and MAN of Buol District in Central Sulawesi with 192 adolescent as the research subjects. In-depth interviews were done to four selected informants. Result and Discussion: The results of bivariate analysis showed a significant relationship between the roles of parents and peers in adolescent premarital sexual behavior. Adolescents with low reproductive health information than that of parents have 2 times higher chance to perform high-risk sexual behaviors than adolescents with high reproductive health information than their parents. Adolescents with peers who give bad influence have a 5 times higher risk sexual behavior than teens with peers whose negative influence is lower. The results of this study also showed that there is a relationship between the influence of religiosity and pornographic media associated with high risk sexual behavior

Conclusion: High-risk sexual behavior in adolescents is influenced by the parents' role, poor informations on reproductive health high bad influence from peers is, low religiosity and exposure to pornographic media.
\end{abstract}

Keywords: role of parents, peers, premarital sexual behavior

\begin{abstract}
ABSTRAK
Latar Belakang: Sebagian besar remaja atau remaja menganggap perilaku seks pranikah adalah kegiatan umum dan normal untuk dilakukan. Orang tua yang kurang mampu berkomunikasi dengan anak-anak mereka dapat menyebabkan dampak pada perilaku seks pranikah pada remaja. Teman sebaya juga merupakan sumber informasi tentang seks yang cukup signifikan dalam membentuk pengetahuan remaja, sikap dan perilaku seksual. Namun, informasi dari teman sebaya dapat menyebabkan dampak negatif pada remaja seperti seks pranikah. Kegiatan ini dapat menyebabkan kehamilan yang tidak diinginkan, IMS, aborsi dan putus sekolah.
\end{abstract}

\footnotetext{
${ }^{1}$ Magister Kesehatan Ibu dan Anak, Departemen Ilmu Kesehatan Masyarakat FKKMK UGM

${ }^{2}$ Department Obstetri \& Ginekologi FKKMK UGM

${ }^{3}$ Konsensus Perlindungan Perempuan UGM
} 
Tujuan: Untuk mengetahui hubungan antara perilaku seksual pranikah di SMAN 1, SMA 2, SMK 1 dan MAN di Buol.

Metode: Penelitian ini adalah observasional dengan desain cross-sectional menggunakan pendekatan kuantitatif dan kualitatif. Penelitian dilaksanakan di SMAN 1, SMAN 2, SMK 1 dan MAN Buol Kabupaten di Sulawesi Tengah dengan 192 remaja sebagai subjek mata pelajaran. Wawancara mendalam dilakukan terhadap empat informan terpilih.

Hasil dan Pembahasan: Hasil analisis bivariat menunjukkan hubungan yang signifikan antara peran orang tua dan teman sebaya pada perilaku seksual pranikah remaja. Remaja dengan informasi kesehatan reproduksi yang rendah dibandingkan dengan orang tua memiliki kesempatan 2 kali lebih tinggi untuk melakukan perilaku seksual berisiko tinggi daripada remaja dengan informasi kesehatan reproduksi yang tinggi daripada orang tua mereka. Remaja dengan teman sebaya yang memberi pengaruh buruk Hasil penelitian ini juga menunjukkan bahwa ada hubungan antara religiusitas dan media pornografi terkait dengan perilaku seksual berisiko tinggi.

Kesimpulan: Perilaku seksual berisiko tinggi pada remaja dipengaruhi oleh peran orang tua, dimana dalam penyediaan peer miskin tinggi, religiusitas rendah dan paparan media pornografi.

Kata Kunci: Peran orang tua, sebaya, perilaku seks pra nikah

\section{PENDAHULUAN}

Remaja perlu mendapatkan perhatian serius karena remaja termasuk dalam usia sekolah dan usia kerja, mereka sangat berisiko terhadap masalah-masalah kesehatan dan sosial, termasuk infeksi menular seksual, kehamilan yang tidak diinginkan, obat-obatan, aktivitas kriminal dan kekerasan. ${ }^{1}$ Beberapa penelitian menunjukkan kasus perilaku seksual remaja dari waktu ke waktu semakin meningkat. Hal ini terjadi karena merosotnya nilai moral masyarakat dan remaja menganggap perilaku seksual pranikah merupakan hal yang wajar dan biasa terjadi. ${ }^{2}$

Kesempatan untuk berdiskusi masalah kesehatan reproduksi masih sangat terbatas, interaksi antara remaja dengan keluarga atau orang tuanya masih kecil karena masih banyak orang tua yang menganggap hal tersebut tabu untuk dibicarakan. Orang tua seharusnya merupakan pihak pertama yang bertanggungjawab memberikan informasi tentang masalah kesehatan reproduksi bagi remaja. Selain itu, pihak sekolah memegang peranan penting dalam memberikan pendidikan seksual untuk memotivasi pilihan yang sehat bagi siswa dalam perilaku seksualnya. ${ }^{3}$

Teman sebaya juga merupakan salah satu sumber informasi tentang seks yang cukup signifikan dalam membentuk pengetahuan, sikap dan perilaku seksual remaja. Informasi dari teman dan buku yang hanya setengah-setengah tanpa pengarahan mudah menjerumuskan. Pengaruh teman sebaya dapat meningkatkan risiko penggunaan alkohol, rokok dan narkoba serta niat dan frekuensi berhubungan seksual. ${ }^{4}$

Religiusitas merupakan salah satu faktor yang mempunyai pengaruh besar dalam perkembangan anak dan remaja, ajaran-ajaran agama dapat membantu menolong mengatasi berbagai hal dalam kehidupan dan merupakan faktor pelindung melawan perilaku berisiko tinggi. $^{5}$ Keikutsertaan remaja dalam kegiatan keagamaan dapat membantu mereka mempunyai strategi pertahanan untuk terhindar dari perilaku risiko tinggi dan cenderung untuk menunda aktivitas seksualnya. ${ }^{6}$ Penelitian Belgrave et $a l^{7}$ 
menemukan bahwa alasan utama responden remajanya tidak melakukan hubungan seksual adalah bukan karena takut terjangkit penyakit menular seksual atau hamil tetapi karena perilaku tersebut bertentangan dengan nilai-nilai moral agamanya.

Collins et al menyimpulkan bahwa menonton adegan-adegan seks di tv dan situs-situs porno mempunyai kontribusi atas terjadinya penyimpangan nilai dan perilaku seksual dengan lawan jenis, mulai dari tingkat yang paling ringan seperti ciuman sampai hubungan seksual. ${ }^{8}$ Berdasarkan laporan dari pihak sekolah, terjadi peningkatan kasus kehamilan remaja sebagai dampak dari perilaku seksual pranikah remaja.

Tujuan mengetahui hubungan antara peran orang tua dan pengaruh teman sebaya dengan perilaku seksual pranikah pada remaja SMA di kabupaten Buol.

\section{METODE}

Penelitian ini merupakan penelitian observasional dengan menggunakan pendekatan kuantitatif dan kualitatif .'Untuk pendekatan kuantitatif digunakan rancangan penelitian potong lintang. Besar sampel dalam penelitian ini adalah 192 orang siswa SMAN 1 Biau, SMAN 2 Biau, SMKN Biau, dan MAN Biau. Cara pengambilan sampel tiap-tiap sekolah untuk penelitian kuantitatif menggunakan proporsional sampling..$^{10}$. Kriteria inklusi yang ditetapkan adalah: 1) bertempat tinggal di Kabupaten Buol dan memiliki alamat jelas; 2 ) bersekolah di SMAN 1, SMAN 2 dan SMKN 1 dan MAN di Kabupaten Buol; dan 3) bersedia menjadi responden dan mengikuti penelitian hingga selesai. Kriteria eksklusi dalam penelitian ini adalah siswa yang berusia $\geq 20$ tahun.

Variabel yang diteliti dalam penelitian ini meliputi: variabel terikat perilaku seksual remaja, variabel bebas yaitu peran orang tua dan teman sebaya. Variabel luar adalah religiusitas, dan pengaruh media porno. Instrumen penelitian ini menggunakan kuesioner meliputi peran orang tua, pengaruh teman sebaya, tingkat religiusitas dan media porno.

Pengumpulan data kuantitatif diperoleh melalui pengisian kuesioner dan data kualitatif melalui wawancara mendalam (indepth interview) kepada empat orang remaja terpilih yang mengetahui persolan yang ingin diteliti.

Analisis bivariat danmultivariatmenggunakan software program Stata Intercooled Versi 11.0 Universitas Gadjah Mada .Uji statistik chi square dan uji regresi logistik dengan tingkat kemaknaan 0,05 dan ratio prevalence (RP), confidence interval (CI) 95\%. Untuk analisis kualitatif digunakan content analysis.

\section{HASIL DAN PEMBAHASAN}

\section{Gambaran Umum Lokasi Penelitian}

Luas wilayah kabupaten Buol adalah 4.043,57 km2. Pusat administrasi Kabupaten Buol terletak di Kelurahan Biau. Kabupaten Buol memiliki 16 SMA yang terdiri dari 11 SMA negeri dan 5 SMA swasta yang tersebar di 11 kecamatan. Penelitian ini mengambil lokasi SMAN 1 terdiri dari 54 siswa, SMAN 2 terdiri dari 36 siswa, SMKN 1 terdiri dari 77 siswa dan MAN yang terdiri dari 25 siswa. 


\section{Analisis Penelitian Kuantitatif}

a. Analisis Univariabel

Tabel 1. Karakteristik variabel yang diteliti

\begin{tabular}{lcc}
\hline Variabel & N & \% \\
\hline Perilaku seksual pranikah remaja & & \\
$\quad$ Perilaku seksual risiko tinggi & 41 & 21,4 \\
$\quad$ Perilaku seksual risiko rendah & 151 & 78,6 \\
$\begin{array}{l}\text { Peran orangtua terhadap pemberian } \\
\text { informasi mengenai kesehatan reproduksi }\end{array}$ & & \\
$\quad$ Rendah & 104 & 54,2 \\
$\quad$ Tinggi & 88 & 45,8 \\
Pengaruh teman sebaya & & \\
$\quad$ Tinggi & 80 & 41,7 \\
$\quad$ Rendah & 112 & 58,3 \\
Religiusitas & & \\
$\quad$ Rendah & 66 & 34,4 \\
$\quad$ Tinggi & 126 & 65,6 \\
Media porno & & \\
$\quad$ Terpapar & 121 & 63,1 \\
Tidak terpapar & 71 & 36,9 \\
\hline
\end{tabular}

Dari tabel 1 terlihat bahwa perilaku seksual risiko tinggi pada responden mencapai $21,4 \%$. Peran orang tua dalam memberikan informasi kesehatan reproduksi rendah pada $52,4 \%$ responden. Responden 63,1\% telah terpapar media porno.

\section{b. Analisis bivariabel}

1). Hubungan antara variabel bebas dengan variabel terikat

Tabel 2. Hubungan variabel bebas dengan perilaku seksual pranikah remaja

\begin{tabular}{|c|c|c|c|c|c|c|c|c|}
\hline \multirow{3}{*}{ Variabel } & \multicolumn{4}{|c|}{ Perilaku seksual pranikah } & \multirow{3}{*}{$\chi^{2}$} & \multirow{3}{*}{$\mathbf{R P}$} & \multirow{3}{*}{$95 \% \mathrm{Cl}$} & \multirow{3}{*}{ p } \\
\hline & \multicolumn{2}{|c|}{$\begin{array}{c}\text { Perilaku seksual } \\
\text { risiko tinggi }\end{array}$} & \multicolumn{2}{|c|}{$\begin{array}{l}\text { Perilaku seksual } \\
\text { risiko rendah }\end{array}$} & & & & \\
\hline & $\mathbf{N}$ & $\%$ & $\mathbf{N}$ & $\%$ & & & & \\
\hline \multicolumn{9}{|c|}{ Peran orangtua terhadap pemberian informasi mengenai kesehatan reproduksi } \\
\hline Rendah & 29 & 27,9 & 75 & 72,1 & 5,76 & 2,04 & $1,11-3,76$ & $0,016^{*}$ \\
\hline Tinggi & 12 & 13,6 & 76 & 86,4 & & & & \\
\hline \multicolumn{9}{|l|}{$\begin{array}{l}\text { Pengaruh teman } \\
\text { sebaya }\end{array}$} \\
\hline Tinggi & 33 & 41,3 & 47 & 58,7 & 32,33 & 5,77 & $2,81-11,83$ & $0,000^{*}$ \\
\hline Rendah & 8 & 7,1 & 104 & 92,9 & & & & \\
\hline
\end{tabular}


Orang tua yang memberikan sedikit informasi mengenai kesehatan reproduksi kepada anaknya berpeluang memiliki anak dengan 2 kali lebih berisiko untuk perilaku seksual risiko tinggi dibandingkan dengan orang tua yang memberikan informasi mengenai kesehatan reproduksi yang tinggi risiko $51,75 \%$ berperilaku seksual risiko tinggi. Pengaruh teman sebaya juga memberikan pengaruh pada perilaku seksual pranikah remaja

\section{2). Hubungan antara variabel luar dengan variabel terikat}

Tabel 3. Hubungan variabel luar dengan perilaku seksual pranikah remaja

\begin{tabular}{|c|c|c|c|c|c|c|c|c|}
\hline \multirow{3}{*}{ Variabel } & \multicolumn{4}{|c|}{ Perilaku seksual pranikah } & \multirow{3}{*}{$\chi^{2}$} & \multirow{3}{*}{$\mathbf{R P}$} & \multirow{3}{*}{$95 \% \mathrm{Cl}$} & \multirow{3}{*}{$\mathbf{P}$} \\
\hline & \multicolumn{2}{|c|}{$\begin{array}{l}\text { Perilaku seksual } \\
\text { risiko tinggi }\end{array}$} & \multicolumn{2}{|c|}{$\begin{array}{l}\text { Perilaku seksual } \\
\text { risiko rendah }\end{array}$} & & & & \\
\hline & $\mathbf{N}$ & $\%$ & $\mathbf{N}$ & $\%$ & & & & \\
\hline \multicolumn{9}{|l|}{ Religiusitas } \\
\hline Rendah & 26 & 39,4 & 40 & 60,6 & 19,49 & 3,30 & $1,88-5,80$ & $0,000 *$ \\
\hline Tinggi & 15 & 11,9 & 111 & 88,1 & & & & \\
\hline \multicolumn{9}{|l|}{ Media porno } \\
\hline Terpapar & 36 & 29,7 & 85 & 70,3 & 13,74 & 4,22 & $1,73-10,27$ & $0,000 *$ \\
\hline Tidak terpapar & 5 & 7,1 & 66 & 92,9 & & & & \\
\hline
\end{tabular}

Remaja dengan tingkat religiusitas yang rendah berpeluang sebesar 3,30 kali untuk berperilaku seksual risiko tinggi dibandingkan remaja yang memiliki tingkat religiusitas yang tinggi, hal ini dapat dilihat dari rasio prevalensi $3,30(95 \% \mathrm{Cl}(1,88-5,80))$.
Hasil analisis untuk variabel media porno, menunjukkan bahwa paparan media porno meningkatkan perilaku seks risiko tinggi sebesar 4,22 kali $90 \% \mathrm{Cl}(1,73-10,27)$.

\section{3). Hubungan antara variabel luar dengan variabel bebas}

Tabel 4. Hubungan variabel luar dengan peran orang tua

\begin{tabular}{|c|c|c|c|c|c|c|c|c|}
\hline \multirow[t]{3}{*}{ Variabel } & \multicolumn{4}{|c|}{$\begin{array}{c}\text { Peran orangtua terhadap } \\
\text { pemberian informasi mengenai } \\
\text { kesehatan reproduksi }\end{array}$} & \multirow[t]{3}{*}{$x^{2}$} & \multirow[t]{3}{*}{$\mathbf{R P}$} & \multirow[t]{3}{*}{$95 \% \mathrm{Cl}$} & \multirow[t]{3}{*}{$\mathbf{P}$} \\
\hline & \multicolumn{2}{|c|}{ Rendah } & \multicolumn{2}{|c|}{ Tinggi } & & & & \\
\hline & $\mathbf{N}$ & $\%$ & $\mathbf{N}$ & $\%$ & & & & \\
\hline \multicolumn{9}{|l|}{ Religiusitas } \\
\hline Rendah & 39 & 59,1 & 27 & 40,9 & 0,98 & 1,14 & $0,88-1,48$ & 0,321 \\
\hline Tinggi & 65 & 51,6 & 61 & 48,4 & & & & \\
\hline \multicolumn{9}{|l|}{ Media porno } \\
\hline Terpapar & 66 & 54,5 & 55 & 45,5 & 0,02 & 1,01 & $0,77-1,33$ & 0,890 \\
\hline Tidak terpapar & 38 & 53,5 & 33 & 46,5 & & & & \\
\hline
\end{tabular}


Hasil analisis pada tabel diatas menunjukkan tidak ada hubungan yang bermakna antara variabel religiusitas dengan peran orang tua $R P$
$0,32195 \% \mathrm{Cl}(0,88-1,48)$. Hasil yang sama terjadi antara media porno dengan peran orang tua $(P R$ $0,89095 \% \mathrm{Cl}(0,77-1,33))$.

\section{c. Analisis Multivariabel}

Tabel 5. Regresi logistic model hubungan peran orangtua terhadap pemberian informasi mengenai kesehatan reproduksi, pengaruh teman sebaya, religiusitas dan media porno dengan perilaku seksual pranikah

\begin{tabular}{|c|c|c|c|c|}
\hline Variabel & $\begin{array}{c}\text { Model } 1 \\
\text { OR } \\
95 \% \mathrm{Cl}\end{array}$ & $\begin{array}{c}\text { Model } 2 \\
\text { OR } \\
95 \% \mathrm{Cl}\end{array}$ & $\begin{array}{c}\text { Model } 3 \\
\text { OR } \\
95 \% \mathrm{Cl}\end{array}$ & $\begin{array}{c}\text { Model } 4 \\
\text { OR } \\
95 \% \mathrm{Cl}\end{array}$ \\
\hline \multicolumn{5}{|c|}{ Peran orangtua terhadap pemberian informasi mengenai kesehatan reproduksi } \\
\hline Rendah & $\begin{array}{c}2,67 \\
(1,18-6,03)\end{array}$ & $\begin{array}{c}2,38 \\
(1,03-5,48)\end{array}$ & $\begin{array}{c}2,90 \\
(1,25-6,69)\end{array}$ & $\begin{array}{c}2,56 \\
(1,09-6,02)\end{array}$ \\
\hline Tinggi & 1 & 1 & 1 & 1 \\
\hline \multicolumn{5}{|l|}{ Pengaruh teman sebaya } \\
\hline Tinggi & $\begin{array}{c}9,51 \\
(4,02-22,51)\end{array}$ & $\begin{array}{c}7,32 \\
(3,03-17,70)\end{array}$ & $\begin{array}{c}7,61 \\
(3,14-18,40)\end{array}$ & $\begin{array}{c}6,14 \\
(2,50-15,12)\end{array}$ \\
\hline Rendah & 1 & 1 & 1 & 1 \\
\hline \multicolumn{5}{|l|}{ Religiusitas } \\
\hline Rendah & & $\begin{array}{c}3,10 \\
(1,38-6,96)\end{array}$ & & $\begin{array}{c}3,02 \\
(1,33-6,87)\end{array}$ \\
\hline Tinggi & & 1 & & 1 \\
\hline \multicolumn{5}{|l|}{ Media porno } \\
\hline Terpapar & & & $\begin{array}{c}3,85 \\
(1,32-11,17)\end{array}$ & $\begin{array}{c}3,79 \\
(1,27-11,31)\end{array}$ \\
\hline Tidak terpapar & & & 1 & 1 \\
\hline $\mathrm{R}^{2}$ & 0,19 & 0,23 & 0,23 & 0,26 \\
\hline Deviance & 160,08 & 152,42 & 152,82 & 145,75 \\
\hline $\mathrm{N}$ & 192 & 192 & 192 & 192 \\
\hline
\end{tabular}

Keterangan:

*= Signifikan $\mathrm{n}=$ Jumlah Sampel $\mathrm{Cl}=$ confidence interval $\mathrm{R} 2=$ Koefisien Determinan

\section{Hasil analisis kualitatif}

Analisis kualitatif dilakukan dengan wawancara mendalam (indepth interview) terhadap 4 orang siswa yang bersedia untuk dilakukan wawancara. Siswa tersebut terdiri dari 1 orang laki-laki dan 3 orang perempuan tentang perilaku seksual pranikah remaja. Remaja sebenarnya telah mendapatkan informasi mengenai kesehatan reproduksi remaja dari orang tuanya tetapi biasanya hanya sebagian saja, tidak secara keseluruhan hal ini dapat dibuktikan dengan hasil wawancara yang dilakukan

"orang tua melarang pacaran, biasanya mama sering menemukan sms saya bersama pacar saya kalau saya lupa mengunci hp saya, kemudian beliau marah dan menasehati kalau ingin pacaran kalau sudah bekerja, karena orang 
tua takut terjadi hal-hal yang tidak diinginkan apalagi saya adalah anak perempuan kalau tibatiba nanti hamil akan membuat orang tua malu. orang tua tidak pernah membahas masalah yang lain-lain hanya takut kalau anaknya hamil." (saudara S)

Teman sebaya merupakan orang yang secara langsung dapat mempengaruhi perilaku remaja termasuk perilaku seksualnya, dari wawancara yang dilakukan, didapatkan hasil sebagai berikut:

"Teman saya ada yang pernah melakukan hubungan seksual kak, kemudian dia menceritakan kepada saya agar supaya saya mau untuk melakukan juga dengan pacar saya, dari ceritanya saya penasaran kak, tapi saya takut juga. Ada juga teman saya yang sudah pacaran yang akhirnya membuat saya terpengaruh untuk pacaran juga. Saya dengan pacar saya hanya sampai ciuman secara lama, kalau hubungan seksual saya takut kak." (Saudara S)

Wawancara mendalam yang dilakukan, menemukan bahwa sebenarnya remaja mengetahui apa yang mereka lakukan itu bertentangan dengan nilai-nilai agama yang mereka anut, tetapi hal itu tidak mengurangi niat mereka untuk pacaran dan melakukan hal-hal yang tidak diperbolehkan agama. Batasan antara hal yang boleh dilakukan dan tidak juga tidak diketahui oleh remaja. Yang mereka tahu bahwa hal yang mereka lakukan dapat menimbulkan dosa.

"sebenarnya saya tahu itu dosa kak, tapi saya takut juga, mau diapakan lagi nasi sudah jadi bubur, nanti juga dia akan menikahi saya ketika lulus sekolah." (Saudara M).

Akses remaja untuk melihat dan mendapatkan informasi mengenai seksualitas melalui media porno sangat mudah, hal ini tidak terlepas dari kemajuan teknologi juga memudahkan remaja untuk dapat mengakses apa yang mereka inginkan tanpa ada pengawasan dari orang tua dan guru-guru. "pernah melihat film porno di hp, dikirim teman. Melihat itu karena penasaran. Biasanya juga melihat gambar porno di internet". (Saudara S).

Perilaku seksual pranikah remaja SMA berada dalam situasi yang sangat memprihatinkan, ratarata remaja mengaku sudah berpacaran lebih dari 10 kali dan melakukan perilaku seksual pranikah remaja yang berisiko tinggi, diantaranya adalah berciuman secara lama, saling merabaraba daerah yang sensitif sampai melakukan hubungan seksual

"ia kak saya sudah pernah melakukan hubungan seksual dengan pacar saya, awalnya dipaksa, tapi sekarang kami sudah melakukannya berkali-kali. Biasanya kami melakukan itu dirumah kalau rumah sedang sepi. Pacarku sudah besar kak, sudah kerja dan dia berjanji akan menikahiku kalau sudah selesai sekolah." (Saudara M)

\section{PEMBAHASAN}

Hasil analisis bivariabel antara peran orang tua dalam hal ini adalah pemberian informasi mengenai kesehatan reproduksi dengan perilaku seksual pranikah remaja menunjukkan hubungan yang bermakna. Hasil ini menjawab hipotesis penelitian bahwa remaja yang mendapatkan informasi mengenai kesehatan reproduksi yang rendah dari orang tuanya memiliki perilaku seksual risiko tinggi dibandingkana remaja yang mendapatkan informasi mengenai kesehatan reproduksi yang tinggi dari orang tuanya. Hal ini sesuai dengan pernyataan bahwa orang tua memegang peranan penting dalam mencegah perilaku seksual pranikah remaja, kedekatan remaja dengan orang tua, remaja yang menjadikan ibu mereka sebagai teman diskusi tentang masalah seksual yang mereka alami bersama pasangannya dan menjadikan ayahnya sebagai contoh atau panutan secara nyata akan terhindar dari perilaku seksual berisiko remaja. ${ }^{11}$ 
Wawancara mendalam yang dilakukan menemukan bahwa orang tua hanya menitikberatkan pada larangan berpacaran tanpa ada informasi yang disampaikan untuk mencegah perilaku tersebut karena masih dianggap tabu, padahal remaja perlu mendapatkan informasi yang benar dan berkesinambungan agar mereka dapat berperilaku/pacaran secara sehat, hal ini sesuai dengan pernyataan yang menyatakan bahwa kesempatan untuk berdiskusi masalah kesehatan reproduksi masih sangat terbatas, interaksi antara remaja dengan orang tuanya masih kecil karena masih banyak orang tua yang mengganggap hal tersebut tabu untuk dilakukan). ${ }^{12}$

Peran orang tua dalam hal ini pemberian informasi mengenai kesehatan reproduksi dapat membantu remaja dalam menentukan perilaku seksualnya, hal ini senada dengan penelitian yang menyatakan bahwa informasi mengenai kesehatan reproduksi yang diberikan oleh orang tua kepada remaja membuat remaja lebih bertanggung jawab atas pilihan perilaku seksual mereka ${ }^{(13)}$. Remaja yang mempunyai hubungan dekat dengan orang tua lebih bisa menerima norma-norma yang berlaku dalam keluarga dan masyarakat terkait batasan perilaku seksual wajar. ${ }^{14}$

Peran orang tua yang mengawasi perkembangan anaknya juga memungkinkan anak untuk menunda hubungan seksualnya meskipun mereka telah bertunangan. ${ }^{15}$

Hasil analisis bivariabel hubungan teman sebaya dengan perilaku seksual pranikah remaja menunjukkan hubungan yang bermakna hal ini sesuai dengan penelitian yang menyatakan bahwa teman sebaya merupakan faktor yang mempunyai pengaruh kuat terjadinya perilaku seksual pranikah remaja, remaja yang mempunyai teman-teman yang telah melakukan aktifitas seksual cenderung melakukan hal yang sama pada usia yang lebih awal .
Dari wawancara mendalam yang dilakukan remaja sering membicarakan masalah seksualnya dengan teman sebayanya yang dianggap mampu untuk menyimpan rahasianya dan remaja juga ada yang terpengaruh dan tidak terpengaruh dari cerita yang disampaikan temannya. Teman sebaya juga menjadi tempat untuk tukar menukar informasi, dimana mereka sering membicarakan hal-hal yang mereka lakukan selama pacaran karena lebih merasa aman bercerita kepada teman sebaya daripada kepada kedua orang tuanya atau guru mereka.

Hal ini sesuai dengan penelitian yang dilakukan yang mengatakan bahwa remaja lebih mengganggap teman sebaya sangat berarti dalam memperoleh informasi yang akan mempengaruhi sikap dan perilaku remaja terhadap isu seksualitas. Keterbatasan informasi mengenai seksualitas terjadi karena orangtua, guru, pendidik, pemuka agama dan tokoh masyarakat merasa takut apabila pemberian informasi dan pendekatan seks kepada remaja akan disalahgunakan mereka. Remaja lebih senang bertanya pada teman sebaya yang tidak lebih baik pengetahuannya dan tidak menerima pendidikan seks bertanggungjawab. Remaja menerima informasi yang salah bahkan menyesatkan misalnya dari cerita teman, melihat dari film atau video porno, tayangan televisi, membaca buku, majalah yang lebih banyak menyajikan seks secara vulgar dibandingkan pengetahuan pendidikan seksual yang benar. ${ }^{16}$

Hasil analisis bivariabel hubungan religiusitas dengan perilaku seksual pranikah remaja menunjukkan hubungan yang bermakna hal ini sesuai dengan penelitian yang dilakukan yang menyatakan bahwa yang menyatakan bahwa religiusitas merupakan salah satu faktor yang mempunyai pengaruh besar dalam perkembangan anak dan remaja, semakin baik tingkat religiusitas remaja akan terhindar dari perilaku menyimpang demikian sebaliknya 
semakin buruk tingkat religiusitas remaja maka akan rentan terhadap perilaku menyimpang diantaranya adalah perilaku seksual pranikah. ${ }^{17}$

Menurut penuturan remaja mereka merasa berdosa bila mereka melakukan perbuatanperbuatan yang mereka anggap dilarang oleh agama tetapi hal tersebut tidak dapat mencegah mereka untuk tidak melakukan hal tersebut, hal ini dikarenakan dasar-dasar pemahaman agama mereka masih sangat minim. Hal ini senada dengan penelitian yang menyatakan bahwa agama, khususnya keterlibatan dalam kegiatan kelompok-kelompok keagamaan dapat mempengaruhi sikap remaja tentang seksualitas. Baiknya religiusitas berhubungan dengan persepsi yang lebih besar terhadap risiko dan penderitaan yang terkait dengan seksualitas dikalangan remaja, religiusitas juga mempengaruhi cara pandang terhadap seksual. ${ }^{18}$

Keikutsertaan remaja dalam jaringan agama dapat membantu mereka mempunyai strategi pertahanan untuk terhindar dari perilaku risiko tinggi dan cenderung untuk menunda aktivitas seksualnya. ${ }^{6}$

Hasil analisis bivariabel hubungan media porno dengan perilaku seksual pranikah remaja menunjukkan hubungan yang bermakna hal ini sesuai dengan penelitian yang dilakukan yang mengatakan bahwa media porno dapat mempengaruhi berbagai sikap dan perilaku remaja. Remaja konsisten untuk mengutip media porno sebagai sumber informasi yang penting tentang seksualitas disamping informasi dari teman sebaya, sekolah dan orang tua. ${ }^{19}$

Dari wawancara mendalam yang dilakukan remaja mengakui bahwa mereka sering menonton film porno melalui media hp dan mengakses situs-situs dewasa dan biasanya mereka menonton bersama teman sebaya dan setelah itu mereka merasa penasaran dan ingin mencoba-coba apa yang diperlihatkan dalam film tersebut. Hasil penelitian ini didukung oleh penelitian yang menyatakan bahwa televisi dan media-media lainnya seperti HP, CD/VCD, internet, radio, surat kabar, tabloid majalah menjadi agen sosialisasi yang sangat kuat dalam kehidupan remaja dan menjadi sumber utama pengetahuan dan nilai-nilai seksual bagi remaja yang tidak mudah dikontrol orang tua. ${ }^{20} \mathrm{Hal}$ ini senada dengan penelitian yang mengatakan bahwa referensi seksual di televisi dan film dapat menjadi kontributor kunci untuk awal koitus, sikap negatif terhadap kondom dan kontrasepsi, memiliki banyak pasangan dan kehamilan remaja. Remaja yang terpapar acara televisi yang mengandung unsur seksualitas yang tinggi dua kali lebih mungkin untuk mengalami kehamilan dalam tiga tahun berikutnya. ${ }^{19}$

\section{KESIMPULAN DAN SARAN}

Perilaku seksual risiko tinggi remaja dipengaruhi oleh pemberian informasi mengenai kesehatan reproduksi yang rendah dari orang tua, pengaruh buruk teman sebaya, religiusitas yang rendah dan keterpaparan media porno.

\section{DAFTAR PUSTAKA}

1. Peres CA, Rutherford G, Borges G, Galano E, Hudes ES, Hearst N. Family Structure and Adolescent Sexual Behavior in a Poor Area of São Paulo, Brazil. Journal of Adolescent Health. 2008;42(2):177-83.

2. World Health Organization. Atlas-Child and Adolescent Mental Health Resources: Global Concerns: Implications for the Future. Geneva: World Health Organization; 2005.

3. Whitaker DJ, Miller KS. Parent-Adolescent Discussions about Sex and Condoms Impact on peer influences of sexual risk behavior. Journal of adolescent Research. 2000;15(2):251-73.

4. Gunarsa YSD, Gunarsa SD. Psikologi Remaja. Jakarta: Gunung Mulia; 2009.

5. Frank NC, Kendall SJ. Religion, risk prevention and health promotion in adolescents: A Comunity based approach. Mental Health Religion \& Culture. 2001;4(2):133-48. 
6. Haglund KA, Fehring RJ. the association of religiosity, sexual education, and parental factors with risky sexual behaviors among adolscents and young adults. Journal of Religion and Health. 2009;32:145-50.

7. Belgrave FZ, van Oss Marian B, Chambers DB. Cultural, contextual. and intapersonal predictors of risky sexual attitudes among urban African American girls in early adolescence. Cultural Diversity and Ethnic Minority Psychology. 2000;6(3):309-22.

8. Collins RL, Elliott MN, Berry SH, Kanouse DE. Watching sex on television predict adolescent initiation of sexual behavior. Pediatrics. 2004;114(3):280-9.

9. Gordis L. Epidemiology. Philadelphia: PA: WB Saunders; 2004.

10. Dahlan S, N. Besar sampel dan cara pengambilan sampel dalam penelitian kedokteran dan kesehatan. Jakarta: Salemba Medika; 2013.

11. Parera N, Suris J-C. Having a Good relationship with their mother: A protective factor against sexual risk behavior among adolescent females? Pediatr Adolesc Gynecol. 2004;17::267-71.

12. Whitaker DJ, Miller KS. Parent-adolescent discussions about sex and condoms impact on peer influences of sexual risk behavior. J Adolesc Res. 2000;15(2):251-73.

13. Coetzee J, Dietrich J, Otwombe K, Nkala B, Khunwane $M$, van der Watt $M$, et al. Predictors of parentadolescent communication in post-apartheid South Africa: A protective factor in adolescent sexual and reproductive health. Journal of Adolescence. 2014;37(3):313-24.

14. Abu PB, Akerele EO. Parental influence on adolescents sexual behaviour in Ibadan North Local Government Area Of Oyo State, Nigeria. International Journal of African \& African American Studies. 2006;5(1):42-56.

15. Wang'eri T, Otanga FH. Family, peer and protective factors related to sex behavior among urban adolescents in secondary schools in Mombasa County, Coast Province, Kenya. International Journal of Education and research. 2013;1(5):1-16.

16. Burgess V, Dziegielewski FS, Green EC. Improving comfort about sex communication between parents and their adolescents: practice based research within a teen sexuality group Brief treatment and crisis intervention 2005;5(4):379-90.

17. Sinha JW, Cnaan RA, Gelles RJ. Adolescent risk behaviors and religion: Findings from a national study. Journal of Adolescence. 2007;30(2):231-49.

18. Deptula DP, Henry DB, Shoeny ME, Slavick JT. Adolescent sexual behavior and attitudes: A costs and benefits approach. Journal of Adolescent Health. 2006;38(1):35-43.

19. Braun-Courville DK, Rojas M. Exposure to Sexually Explicit Web Sites and Adolescent Sexual Attitudes and Behaviors. Journal of Adolescent Health. 2009;45(2):156-62.

20. Hallstead JM, Reiss M. Values in sex education : from principles to practice Jogjakarta: Alenia Press; 2004. 